\title{
Soil salinity, micronutrients and passion fruit production irrigated with saline water and using organomineral fertilization
}

Salinidade do solo, micronutrientes e produção do maracujazeiro irrigado com água salina e adubação organomineral

\author{
J. T. A. Souza ${ }^{1 *}$; L. F. Cavalcante ${ }^{2,3}$; J. C. Nunes ${ }^{4}$; D. L. Araújo²; F. F. Oliveira ${ }^{5}$ \\ ${ }^{1}$ Instituto Nacional do Semiárido, 58434-700, Campina Grande - Paraíba, Brasil \\ ${ }^{2}$ Universidade Federal da Paraíba, Programa de Pós-Graduação em Agronomia, 58397-000, Areia -Paraíba, Brasil \\ ${ }^{3}$ Instituto Nacional de Ciência e Tecnologia em Salinidade, 60440-554, Fortaleza-Ceará, Brasil \\ ${ }^{4}$ Universidade Estadual da Região Tocantina do Maranhão, Centro de Ciências Agrárias, Naturais e Letras, 65900- \\ 000, Maranhão, Brasil \\ ${ }^{5}$ Programa de Pós-Graduação em Ciência do Solo, Universidade Federal Rural de Pernambuco, 52171-900, Recife - \\ Pernambuco, Brasil. \\ *thyago.agro@hotmail.com
}

(Recebido em 10 de fevereiro de 2020, aceito em 21 de julho de 2020)

\begin{abstract}
The experiment was conducted in the city of Remigio, Paraiba State, Brazil, from July/2013 to May/2014. The aim of this work is to evaluate the effects of the saline water, bovine biofertilizer and potassium source on soil salinity, micronutrients and sodium contents in the leaf dry matter, and on the production of yellow passion fruit plants cv BRS Gigante Amarelo. The treatments were distributed in randomized blocks subdivided into plots using the factorial scheme $2 \times(2 \times 2)$. It refers to the main plot as two different irrigation waters with electrical conductivities of 0.35 and $4.00 \mathrm{dS} \mathrm{m}^{-1}$, and the subplots as the combination between the biofertilizer application and exemption with different potassium sources: the conventional potassium chloride $(\mathrm{KCl})$ and the polymer-coated one. The increase in the electrical conductivity of the irrigation water increased the initial soil salinity from 0.36 to 3.43 and after to $5.43 \mathrm{dS} \mathrm{m}^{-1}$. It also increased the leaf contents of $\mathrm{Fe}^{2+}$ and $\mathrm{Na}^{+}$. The biofertilizer increased the $\mathrm{Zn}^{2+}$ content in the leaf dry matter of the passion fruit plants, while the fertilization with polymer-coated $\mathrm{KCl}$ increased the $\mathrm{B}$ content and reduced the $\mathrm{Mn}^{2+}$ one as compared to the conventional $\mathrm{KCl}$. The plants, at the beginning of the flowering phase, although their deficiencies of all micronutrients, presented satisfactory productivity levels whether the national average numbers are considered.
\end{abstract}

Keywords: Passiflora edulis, potassium chloride, organic input.

O experimento foi conduzido no município de Remígio, Estado da Paraíba, Brasil, no período de julho/2013 a maio/2014, para avaliar os efeitos da salinidade da água de irrigação, biofertilizante bovino e tipos de potássio na salinidade do solo, conteúdo foliar de micronutrientes e sódio na matéria seca foliar e produção do maracujazeiro cv Gigante Amarelo. Os tratamentos foram distribuídos em blocos casualizados em parcela subdividida usando fatorial $2 \times(2 \times 2)$, referente a duas condutividades elétricas da água de irrigação $(0,35$ e 4,00 dS m ${ }^{-1}$ ) como parcela principal e as subparcelas pela combinação da ausência e presença de biofertilizante com diferentes fontes de potássio, sendo o cloreto de potássio $(\mathrm{KCl})$ convencional e revestido com polímeros orgânicos. O aumento da condutividade elétrica da água de irrigação elevou a salinidade inicial do solo de 0,36 para 3,44 e 5,43 $\mathrm{dS} \mathrm{m}^{-1}$, elevou também os teores foliares $\mathrm{de}^{2+} \mathrm{e} \mathrm{Na}^{+}$. O biofertilizante incrementou os teores de $\mathrm{Zn}^{2+}$ na matéria seca foliar do maracujazeiro e a adubação com $\mathrm{KCl}$ revestido com polímeros elevou o teor de $\mathrm{B}$ e reduziu o de $\mathrm{Mn}^{2+}$ em comparação ao $\mathrm{KCl}$ convencional. As plantas, no início da floração, apesar de estarem deficientes em todos os micronutrientes, produziram satisfatoriamente quando comparado à média nacional.

Palavras-chave: Passiflora edulis, cloreto de potássio, insumo orgânico.

\section{INTRODUCTION}

The fruticulture represents one of the important segments of Brazilian agriculture. It is responsible for a large part of national agricultural production. Among the fruit trees, the yellow passion fruit plant (Passiflora edulis Sims) has been outstanding due to its production capacity throughout the year and socioeconomic importance, since it is cultivated predominantly in small 
and medium orchards, Brazil being the largest fruit producer in the world [27]. In 2017, Brazil produced 548,088 $\mathrm{t}$ of passion fruit, yielding $13.3 \mathrm{t} \mathrm{ha}^{-1}$. The Brazilian northeast region contributed to most part of the production levels $(333,027 \mathrm{t})$. However, the passion fruit productivity for this region $\left(12.0 \mathrm{t} \mathrm{ha}^{-1}\right)$ is lower than the national average numbers.

One of the limitations to crop production in most part of the Brazilian northeast is the quality of irrigation water; many sources have a salinity level that inhibits growth, causes nutritional disturbance and crop production damages [10,34]. Even considering this limitation, the world is increasingly proposing the use of waters restricted by their salinity in the production of the crops in general, mainly due to the scarcity of water in quality and quantity for agriculture in this region $[5,24]$. For this reason, although the yellow passion fruit plant undergoes depressive effects from both, ionic concentration and species $[13,15,30]$, it is necessary to search for alternatives that can guarantee the appropriate fruit production as well.

In soils affected by salts, where the osmotic potential of the soil solution decreases and, consequently, there is an increase in the energy expenditure by the plants during the absorption process, it is essential to adopt management actions to reduce the degenerative effects of the salts on the plants. Among these actions, the adequate supply of nutrients with sufficient dosages and assimilable forms to the plants favor the stabilization of orchards. In this context, potassium fertilization plays an important role in the availability of other elements, including micronutrients, enzyme activation, protein synthesis, photosynthesis, turgor and osmotic regulation [14, 18, 39].

The potassium sources, which are readily assimilable by the plants in places where the irrigation water presents restrictions, can promote the nutritional balance and crop production. Additionally to the fact of maintaining suitable levels of potassium in the edaphic environment, the use of organic inputs can physically improve the porous media [6]. The chemical and biological availability of macro and micronutrients [28] allow a crop performance improvement in environments affected by salts. The biofertilizer provided by the anaerobic fermentation of fresh manure from lactating cows combined with the water applied to the soil attenuates the aggressive effects of the salts on the formation of yellow passion fruit seedlings (Passiflora edulis) [22], plant growth after its transposition [34] and fruit quality [1]. When these results are considered, it can be inferred that the application of organic material on the soil possibly attenuates the deleterious effects of the salts on the micronutrients composition and production of yellow passion fruit.

The production potential of the yellow passion fruit plant, mainly under strict conditions, is only reached whether the plants were nutritionally balanced. The micronutrients have vital functions in the plants metabolism. They will participate in the metabolic processes and enzymatic activities [21]. Under cultivating conditions of restricted irrigation water, the increase in the chloride and sodium contents may reduce the absorption of macronutrients, including the potassium, which compromises the membrane and enzymatic performance. Thus, the use of a source of readily assimilable potassium or a controlled release of this element [40] could improve the nutritional balance by reducing the deleterious effects on the production of passion fruits.

Based on what was herein exposed, the aim of this work is to evaluate the effects of the irrigation water, bovine biofertilizer application and potassium sources on soil salinity, leaf macronutrients contents and on production components of the passion fruit plants cv BRS Gigante Amarelo (GA1).

\section{MATERIAL AND METHODS}

A field experiment was conducted in the city of Remígio, Paraíba State, Brazil, located by the geographic coordinates of $7^{\circ} 00^{\prime} 1.95^{\prime \prime} \mathrm{S}, 35^{\circ} 47^{\prime} 55^{\prime \prime} \mathrm{W}$ and altitude of $562 \mathrm{~m}$, during the period of July 2013 to May 2014. The city climate is type As' which means hot and humid with a rainy period from March to July [2]. The rainfall was read at the rain gauge installed in the experimental field and it was $640 \mathrm{~mm}$ over the experimental time.

Before setting up the experiment, soil samples were collected for a $0.0-0.40 \mathrm{~m}$ layer and according to methodologies of Brazilian Soil Classification System criteria [11], the soil of the experimental area has been classified as Regosols (which is in accordance with WRB/FAO classification). Regarding its salinity, the soil is a non-saline one [31]. The physical and chemical features of the soil and bovine manure (Table 1) were obtained using the methodologies previously used by Embrapa (2013) [12]. 
Table 1: Physical and chemical characterization of the soil, in a 0.0-0.40 m layer, and soil fertility and bovine manure.

\begin{tabular}{lclcc}
\hline Physical attributes & Value & Chemical attributes & Value & Bovine manure \\
\hline $\mathrm{BD}\left(\mathrm{g} \mathrm{cm}^{-3}\right)$ & 1.60 & $\mathrm{pH}$ & 6.10 & 8.64 \\
$\mathrm{PD}\left(\mathrm{g} \mathrm{cm}^{-3}\right)$ & 2.66 & $\mathrm{P}\left(\mathrm{mg} \mathrm{dm}^{-3}\right)$ & 17.78 & 36.11 \\
$\mathrm{TP}(\%)$ & 0.39 & $\mathrm{~K}\left(\mathrm{mg} \mathrm{dm}^{-3}\right)$ & 78.69 & 7892.30 \\
Sand $\left(\mathrm{g} \mathrm{kg}^{-1}\right)$ & 834.00 & $\mathrm{Na}^{+}\left(\mathrm{cmol}_{\mathrm{c}} \mathrm{dm}^{-3}\right)$ & 0.07 & 3.86 \\
Silt $\left(\mathrm{g} \mathrm{kg}^{-1}\right)$ & 113.00 & $\mathrm{H}^{+} \mathrm{Al}^{3+}\left(\mathrm{cmol}_{\mathrm{c}} \mathrm{dm}^{-3}\right)$ & 1.40 & 1.24 \\
Say $\left(\mathrm{g} \mathrm{kg}^{-1}\right)$ & 53.00 & $\mathrm{Al}^{3+}\left(\mathrm{cmol}_{\mathrm{c}} \mathrm{dm}^{-3}\right)$ & 0.00 & 0.00 \\
$\mathrm{Cdw}\left(\mathrm{g} \mathrm{kg}^{-1}\right)$ & 13.00 & $\mathrm{Ca}^{2+}\left(\mathrm{cmol}_{\mathrm{C}} \mathrm{dm}^{-3}\right)$ & 2.32 & 5.40 \\
FDS $(\%)$ & 75.40 & $\mathrm{Mg}^{2+}\left(\mathrm{cmol}_{\mathrm{c}} \mathrm{dm}^{-3}\right)$ & 0.47 & 4.50 \\
SDI $(\%)$ & 24.50 & $\mathrm{SB}\left(\mathrm{cmol}_{\mathrm{c}} \mathrm{dm}^{-3}\right)$ & 3.07 & - \\
Smfc $\left(\mathrm{g} \mathrm{kg}^{-1}\right)$ & 98.60 & $\mathrm{CEC}\left(\mathrm{cmol}_{\mathrm{c}} \mathrm{dm}^{-3}\right)$ & 4.47 & - \\
Smpwp $\left(\mathrm{g} \mathrm{kg}^{-1}\right)$ & 44.00 & $\mathrm{~V}(\%)$ & 68.59 & - \\
Aw $\left(\mathrm{g} \mathrm{kg}^{-1}\right)$ & 54.60 & $\mathrm{OM}\left(\mathrm{g} \mathrm{kg}^{-1}\right)$ & 5.27 & 591.68 \\
TC & Sandy & & - & -
\end{tabular}

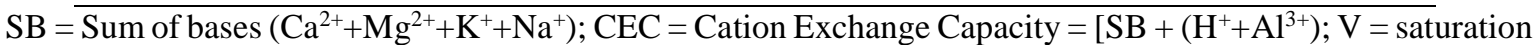
by exchangeable bases $(\mathrm{SB} / \mathrm{CTC}) 100 ; \mathrm{OM}=$ organic matter; $\mathrm{BD}=$ bulk density; $\mathrm{PD}=$ particle density; $\mathrm{TP}=$ total porosity; FDS = flocculation degree of soil; SDI = soil dispersion index $=100-\mathrm{FDS} ; \mathrm{Cdw}=$ clay dispersed in water; $\mathrm{Aw}=$ available water; $\mathrm{TC}=$ textural classification; $\mathrm{Smfc}=$ soil moisture at field capacity; $\mathrm{Smpwp}=$ Soil moisture at permanent wilting point.

The soil, irrigation water and diluted bovine biofertilizer (1:1 or $50 \%$ dilution in water) were evaluated in terms of salinity (Table 2) in the Laboratório de Física e Quimíca do Solo from the Agriculture Science Center at the Universidade Federal da Paraíba using the methodologies proposed by Richards (1954) [31].

Table 2: Soil (a 0.0 - $0.40 \mathrm{~m}$ layer), irrigation water and diluted bovine biofertilizer (1:1 or $50 \%$ dilution in water) characterization in terms of salinity.

\begin{tabular}{lcccc}
\hline \multicolumn{1}{c}{ Variable } & Soil & $\mathrm{W}_{1}$ & $\mathrm{~W}_{2}$ & Biofertilizer \\
\hline $\left.\mathrm{EC}(\mathrm{dS} \mathrm{m})^{-1}\right)$ & 0.36 & 0.35 & 4.00 & 3.10 \\
$\mathrm{pH}$ & 6.80 & 6.12 & 6.25 & 6.37 \\
$\mathrm{Ca}^{2+}\left(\mathrm{mmol}_{\mathrm{c}} \mathrm{L}^{-1}\right)$ & 0.79 & 1.19 & 2.51 & 6.97 \\
$\mathrm{Mg}^{2+}\left(\mathrm{mmol}_{\mathrm{c}} \mathrm{L}^{-1}\right)$ & 0.68 & 0.59 & 7.92 & 8.85 \\
$\mathrm{Na}^{+}\left(\mathrm{mmol}_{\mathrm{c}} \mathrm{L}^{-1}\right)$ & 1.71 & 1.48 & 29.31 & 4.18 \\
$\mathrm{~K}^{+}\left(\mathrm{mmol}_{\mathrm{c}} \mathrm{L}^{-1}\right)$ & 0.45 & 0.19 & 0.38 & 10.47 \\
$\mathrm{Cl}^{-}\left(\mathrm{mmol}_{\mathrm{c}} \mathrm{L}^{-1}\right)$ & 2.29 & 2.51 & 35.56 & 21.97 \\
$\mathrm{CO}_{3}{ }^{2-}\left(\mathrm{mmol}_{\mathrm{c}} \mathrm{L}^{-1}\right)$ & 0.00 & $\mathrm{Abs}$ & 0.11 & $\mathrm{Abs}$ \\
$\mathrm{HCO}^{-}\left(\mathrm{mmol}_{\mathrm{c}} \mathrm{L}^{-1}\right)$ & 0.75 & 0.54 & 2.85 & 4.65 \\
$\mathrm{SO}^{2-}{ }_{4}\left(\mathrm{mmol}_{\mathrm{c}} \mathrm{L}^{-1}\right)$ & 0.49 & 0.36 & 0.24 & 3.53 \\
$\mathrm{SAR}\left(\mathrm{mmol} \mathrm{L}^{-1}\right)$ & 2.01 & 1.57 & 12.85 & 1.49 \\
$\mathrm{ESP}(\%)$ & 1.56 & -- & --- & --- \\
\hline $\mathrm{Classification}$ & $\mathrm{NS}$ & ${ }^{*} \mathrm{C}_{1} \mathrm{~S}_{1}$ & $* \mathrm{C}_{4} \mathrm{~S}_{1}$ & ${ }^{*} \mathrm{C}_{4} \mathrm{~S}_{1}$ \\
\hline
\end{tabular}

$\overline{\mathrm{EC}}=$ electrical conductivity; $\mathrm{SAR}=$ sodium adsorption ratio $=\mathrm{Na}^{+} /\left[\left(\mathrm{Ca}^{2+}+\mathrm{Mg}^{2+}\right) / 2\right] 1 / 2 ; \mathrm{ESP}=$ exchangeablesodiumpercentage $=100(\mathrm{Na}+\mathrm{CTC}) ; \mathrm{NS}=$ Non saline; $\mathrm{W} 1=$ surface dam water; $\mathrm{W} 2=$ water rich in sodium chloride; $\mathrm{C} 1$ and $\mathrm{C} 4=$ respectively low and high risk of soil salinity; $\mathrm{S} 1=$ below sodification soil risk with irrigation, $\mathrm{Bio}=$ bovine biofertilizer; Abs = absence; * = Ayers and Westcot (1999).

For statistical puposes, the treatments were distributed in randomized blocks subdivided into plots using the factorial scheme $2 \times(2 \times 2)$ and with three replications. The main plot is related to two different irrigation waters with electrical conductivities of 0.35 and $4.00 \mathrm{dS} \mathrm{m}^{-1}$, and the subplots are a combination between the biofertilizer application and exemption in soil with different 
potassium sources: the conventional potassium chloride $(\mathrm{KCl})$ and the polymer-coated one. The total area of the experimental field is $576 \mathrm{~m}^{2}$ with 96 plants. The experimental unit with a total area of $24 \mathrm{~m}^{2}$ was composed by four passion fruit plants. The bovine biofertilizer referring to soil without and with bovine biofertilizer at levels of 0 and $50 \%$ from a dosage of $15 \mathrm{~L} \mathrm{~m}^{-2}$ [26] and two sources of potassium were conventional potassium chloride and slow release potassium chloride (coated with polymers, both with $60 \% \mathrm{~K}_{2} \mathrm{O}$ ). The decision of use a coat of polymers was made based on Yang et al. (2017) [40]. According to their study, coating the fertilizer with polymers allows the gradual release of potassium to plants over the time.

The pits were opened in the dimensions of $0.4 \mathrm{~m} \times 0.4 \mathrm{~m} \times 0.4 \mathrm{~m}$ and prepared with soil material of the first $20 \mathrm{~cm}$. Because the soil contained an average level of calcium and low concentrations of magnesium and sulfur (Table 1), it was necessary the addition of a $100 \mathrm{~g}$ mixture containing $75 \%$ limestone $(48 \% \mathrm{CaO}, 3.8 \% \mathrm{MgO}$ and $78 \%$ PRNT), $25 \%$ of agricultural gypsum $\left(\mathrm{CaSO}_{4} \cdot 2 \mathrm{H}_{2} \mathrm{O}\right)$ with $24 \% \mathrm{CaO}, 16 \% \mathrm{~S}, 0,81 \% \mathrm{P}_{2} \mathrm{O}_{5}$ and $14 \%$ of moisture with $10 \mathrm{~L}$ of bovine manure with $\mathrm{C} / \mathrm{N}$ ratio of $18: 1$, discounted $5 \%$ of gravimetric humidity.

The seedlings were produced using seeds of the 'BRS Giant Yellow' passion fruit genotype in a substrate containing two parts of the first $20 \mathrm{~cm}$ of soil material from the experimental area, part of the same bovine manure incorporated into the pits and $1 \% 18 \% \mathrm{P}_{2} \mathrm{O}_{5}, 14.0 \% \mathrm{Ca}, 3.5 \% \mathrm{Mg}, 10.0 \%$ $\mathrm{S}, 0.15 \% \mathrm{~B}, 0.18 \% \mathrm{Cu}$ and $0.65 \% \mathrm{Zn}$ ). Before plants transposition in the second fortnight of July/2013, $3 \mathrm{~g}$ of urea $(45 \% \mathrm{~N}), 5 \mathrm{~g}$ of simple superphosphate $\left(18 \% \mathrm{P}_{2} \mathrm{O}_{5}, 18.0 \% \mathrm{Ca}\right.$ and $\left.10.0 \% \mathrm{~S}\right)$ and $3 \mathrm{~g}$ of each potassium source with $60 \% \mathrm{~K}_{2} \mathrm{O}$ were added to the seedlings with an average height of $25 \mathrm{~cm}$ and four pairs of leaves. Nitrogen fertilization with urea and potassium, from each potassium chloride, were performed every month [7]. Phosphorus addition as a single superphosphate was conducted every two months. All these increments were made between $07 / 16 / 2013$ and $05 / 15 / 2014$. The support system for plants sustentation was espalier with a smooth wire $\mathrm{n}^{\circ} 12$ installed at the top of the stakes with a length of $2.2 \mathrm{~m}$.

Irrigation water with low salinity $\left(0.35 \mathrm{dS} \mathrm{m}^{-1}\right)$ was obtained from a surface dam and the one with an electrical conductivity of $4.00 \mathrm{dS} \mathrm{m}^{-1}$ was obtained by adding non-iodized sodium chloride ( $92 \%$ in purity) to water from the dam. The biofertilizer was produced by the anaerobic fermentation of fresh manure from lactating cows and water [26], supplied on a blade of $6 \mathrm{~L} \mathrm{~m}^{-2}$, corresponding to $50 \%$ of the recommended $15 \mathrm{~L} \mathrm{~m}^{-2}$, after diluted in the dam water in a ratio of $1: 1$, one day before and every 90 days after transplanting the seedlings - DAT, in an area of $0.8 \mathrm{~m}^{2}$ of a circumference of $50 \mathrm{~cm}$ radius having the plant as the center of the pit. In each application of the biofertilizer the plants without the input were irrigated with the same volume of each type of water used for irrigation discounted the value of the irrigation blade.

The crop irrigation was accomplished by a dripping system irrigation with two drips by plant at a flow rate of $10 \mathrm{~L} \mathrm{~h}^{-1}$. The water blade thickness, applied every 48 hours, was defined in accordance with the maximal water blade thickness corresponding to the daily crop evapotranspiration (14 $\mathrm{L}$ plant $^{-1}$ day $\left.^{-1}\right)$. It is determined by the product between the potential evapotranspiration (ETo) and the crop coefficient $(\mathrm{Kc})$ during different phases of the cultivation $(\mathrm{ETc}=\mathrm{ETo} \times \mathrm{Kc})$. The ETo was calculated by the product between the evaporation rate in the Class 'A' pan (ETa) and the correction factor of 0.75 for covered soils. The crop coefficients - Kc were: $0.43,0.94$ and 1.0 for the vegetative, flowering and fruiting phase, respectively [25]. In the treatments with high salinity waters, it was applied a leaching fraction of $10 \%$ of the water blade thickness in order to lixiviate salts from the plants root environment [4].

The yellow passion fruit crop was implanted in a $3 \times 2 \mathrm{~m}$ spatial arrangement, corresponding to a density of 1667 plants per hectare. When the plants were in full blooming at 115 DAT, simple soil samples were collected from each quadrant of the plants, at a depth of 0.0-0.40 m, and transformed by repetition into a composed sample to evaluate the salinity in the plants root environment [31].

When the soil samples were collected, leaf tissue samples were also withdrawn to evaluate the nutritional conditions of the plants in terms of micronutrients (B, Cu. Fe, $\mathrm{Mn}$ and $\mathrm{Zn}$ ) and sodium. For each treatment were collected 24 leafs using the criterion of collecting the forth leaf from the apical meristem of the intermediary productive and healthy stems [20]. The measurements were carried out applying the methodology suggested by Embrapa (2019) [12]. The leaves were washed by immersion in tap water and subsequently in deionized water. The material was allowed to dry 
in an oven with air circulation at a temperature of $65^{\circ} \mathrm{C}$ for 72 hours. After, they were ground in a Wiley mill type TE - $650^{\circledR}$ and refined using 20 mesh sieve.

The fruits presenting at least $40 \%$ of the area in yellow color were daily harvested, from March to May 2014; then they were packed in plastic boxes, always counting the number of fruits per plant and total productivity.

The results were submitted to the analysis of variance by the F-test and the means of the interactions were compared applying Tukey's test at a probability level of $5 \%$ on the Statistical Analysis System software (SAS/STAT 9.3, 2011) [32].

\section{RESULTS AND DISCUSSION}

The leaf copper contents, the number of fruits by plant and the productivity have not responded to the effects caused by any source of variation (Table 3 ). The interaction of water $\times$ potassium $\times$ biofertilizer interfered significantly on the leaf contents of boron and iron. The electrical conductivity of the soil saturation extract was influenced by the interactions between water salinity and potassium, and water salinity and biofertilizer. It was also observed that the interaction between water irrigation type $\times$ biofertilizer and the isolated effects of potassium influenced the leaf sodium content; the foliar accumulation of manganese and zinc is a response to the isolated action of potassium and bovine biofertilizer, respectively.

Table 3: Summary of the analysis of variance by the mean square for electrical conductivity of the soil saturation extract (CEes from a 0-40 cm layer), leaf contents of micronutrients and sodium, number of fruits by plants (NFP) and productivity of the passion fruit plant 'BRS Gigante Amarelo'.

\begin{tabular}{|c|c|c|c|c|c|c|c|c|c|c|}
\hline \multirow{2}{*}{$\begin{array}{l}\text { Source of } \\
\text { variation }\end{array}$} & \multirow[b]{2}{*}{$\begin{array}{l}\text { G } \\
\mathrm{L}\end{array}$} & \multicolumn{9}{|c|}{ Mean square } \\
\hline & & Ecse & B & $\mathrm{Cu}$ & $\mathrm{Fe}$ & $\mathrm{Mn}$ & $\mathrm{Zn}$ & $\mathrm{Na}$ & NFP & PT \\
\hline Block & 2 & $0.04^{\mathrm{ns}}$ & $0.01^{\mathrm{ns}}$ & $8.00^{\mathrm{ns}}$ & $0.50^{\mathrm{ns}}$ & $34.03^{\mathrm{ns}}$ & $\underset{s}{10.12^{n}}$ & $2301^{\mathrm{ns}}$ & $88.79^{\mathrm{ns}}$ & $\begin{array}{c}17.83^{\mathrm{n}} \\
\mathrm{s}\end{array}$ \\
\hline Water (W) & 1 & $\begin{array}{c}29.30^{*} \\
*\end{array}$ & $3.37^{* *}$ & $\begin{array}{c}24.00^{\mathrm{n}} \\
\mathrm{s}\end{array}$ & $\underset{s}{433.50^{\mathrm{n}}}$ & $2.34^{\mathrm{ns}}$ & $0.37^{\mathrm{ns}}$ & $1145^{* *}$ & $45.37^{\mathrm{ns}}$ & $5.30^{\mathrm{ns}}$ \\
\hline Residue (a) & 2 & 0.02 & 0.00 & 8.00 & 36.12 & 52.53 & 8.00 & 2308 & 227.72 & 32.53 \\
\hline Potassium (K) & 1 & $0.34^{* *}$ & $0.37^{\mathrm{ns}}$ & $\begin{array}{c}24.00^{\mathrm{n}} \\
\mathrm{s}\end{array}$ & $54.00^{\mathrm{ns}}$ & $\underset{*}{41.34^{*}}$ & $6.00^{\mathrm{ns}}$ & $8252^{* *}$ & $3.01^{\mathrm{ns}}$ & $0.27^{\mathrm{ns}}$ \\
\hline Biofertilizer (B) & 1 & $2.03^{* *}$ & $1.50^{\mathrm{ns}}$ & $\begin{array}{c}24.00^{\mathrm{n}} \\
\mathrm{s}\end{array}$ & $37.50^{\mathrm{ns}}$ & $0.09^{\text {ns }}$ & $18.37^{*}$ & $2311^{* *}$ & $0.16^{\mathrm{ns}}$ & $4.38^{\mathrm{ns}}$ \\
\hline $\mathrm{W} \times \mathrm{K}$ & 1 & $0.19^{*}$ & $9.37^{\mathrm{ns}}$ & $\begin{array}{c}24.00^{\mathrm{n}} \\
\mathrm{s}\end{array}$ & $63.37^{\mathrm{ns}}$ & $4.59^{\mathrm{ns}}$ & $9.37^{\mathrm{ns}}$ & $6309^{n s}$ & $66.66^{\mathrm{ns}}$ & $\underset{s}{22.58^{n}}$ \\
\hline $\mathrm{W} \times \mathrm{B}$ & 1 & $0.23^{* *}$ & $\underset{*}{37.50}$ & $\begin{array}{c}24.00^{\mathrm{n}} \\
\mathrm{s}\end{array}$ & $234.37^{*}$ & $2.34^{\mathrm{ns}}$ & $\begin{array}{c}13.50^{\mathrm{n}} \\
\mathrm{s}\end{array}$ & $2396^{* *}$ & $19.26^{\mathrm{ns}}$ & $1.00^{\mathrm{ns}}$ \\
\hline $\mathrm{K} \times \mathrm{B}$ & 1 & $0.10^{\mathrm{ns}}$ & $1.50^{\mathrm{ns}}$ & $\begin{array}{c}24.00^{\mathrm{n}} \\
\mathrm{s}\end{array}$ & $18.37^{\mathrm{ns}}$ & $4.59^{\mathrm{ns}}$ & $9.37^{\mathrm{ns}}$ & $76^{\mathrm{ns}}$ & $15.04^{\mathrm{ns}}$ & $4.02^{\mathrm{ns}}$ \\
\hline $\mathrm{W} \times \mathrm{K} \times \mathrm{B}$ & 1 & $0.01^{\mathrm{ns}}$ & $\underset{*}{37.50}$ & $\begin{array}{c}24.00^{\mathrm{n}} \\
\mathrm{s}\end{array}$ & $96.00^{*}$ & $0.84^{\mathrm{ns}}$ & $\begin{array}{c}13.50^{\mathrm{n}} \\
\mathrm{s}\end{array}$ & $1550^{\mathrm{ns}}$ & $243.84^{\mathrm{ns}}$ & $\underset{\mathrm{s}}{12.45^{\mathrm{n}}}$ \\
\hline Residue (b) & 12 & 0.03 & 7.41 & 8.00 & 17.47 & 2.19 & 3.64 & 2089 & 94.12 & 12.04 \\
\hline $\mathrm{CV}$ a $(\%)$ & & 4.19 & 0.05 & 41.42 & 7.52 & 31.43 & 15.08 & 17.73 & 4.19 & 1.70 \\
\hline $\mathrm{CV} b(\%)$ & & 4.87 & 9.94 & 41.42 & 5.23 & 6.41 & 10.17 & 16.87 & 1.73 & 0.63 \\
\hline & & & & & & & & & $\begin{array}{c}\text { fruits } \\
\text { plant }^{-1}\end{array}$ & $\mathrm{t} \mathrm{ha}^{-1}$ \\
\hline Average & & 3.89 & 27.38 & 2.00 & 79.88 & 23.06 & 18.75 & 2709.50 & 54.27 & 19.05 \\
\hline
\end{tabular}

DF = Degrees of Freedom; ns: Not significant, * significant at 5\%, ** significant at 1\%. Two residues in the variance analysis refer to: (i) main plot (residue a) - irrigation water and (ii) subplots (residue b) combination of the sources of variation, such as the potassium source and biofertilizer application.

The water irrigation influenced the electrical conductivity of the soil saturation extract and leaf contents of boron and sodium (Table 3), probably because of the concentration of cations $\left(\mathrm{Na}^{+}\right.$, $\left.\mathrm{Ca}^{2+}, \mathrm{Mg}^{2+} \mathrm{e} \mathrm{K}^{+}\right)$and anions $\left(\mathrm{Cl}^{-}, \mathrm{SO}_{4}^{2-}, \mathrm{HCO}^{3-}, \mathrm{CO}_{3}^{2-}\right)$ expressed in the Table 2. The boron 
accumulation in the leaf tissue is limited by the high potassium, calcium and magnesium contents in the soil [28]. The potassium sources influenced the electrical conductivity of the saturation extract and leaf contents of manganese and sodium (Table 3 ). The $\mathrm{K}^{+}$supply and the increase of its availability in soil due to the polymer-coated $\mathrm{KCl}$ [35] have contributed to elevate the levels of ECse, however, there was a reduction in the leaf manganese contents due to the antagonistic relationship between the potassium contents in soil and the manganese accumulation in the plant [28]. The high leaf sodium contents can be attributed to the strong competition between $\mathrm{Na}^{+}$and $\mathrm{K}^{+}$. The bovine biofertilizer interfered in ECse values and leaf contents of zinc and sodium. These results can be explained by the electrical conductivity of the organic compounds (Table 2) and by the contents of zinc $\left(148.5 \mathrm{mg} \mathrm{kg}^{-1} \mathrm{Zn}\right)$ and sodium $\left(2975.0 \mathrm{mg} \mathrm{kg}^{-1} \mathrm{Na}\right)$ in the leaf dry matter before the dilution of $50 \%$ in water.

The low mean copper content of $2 \mathrm{mg} \mathrm{kg}^{-1}$ (Table 3), out of the range of 10 to $20 \mathrm{mg} \mathrm{kg}^{-1}$ required by crop [20] indicates that the plants were deficient in this element. This mean content value is significantly lower than the lowest content value of $12.10 \mathrm{mg} \mathrm{kg}^{-1}$ registered by Freire et al. (2015) [14] evaluating the same crop production under irrigation with low and high salinity water in soil without and with bovine biofertilizer. Although Fosmag $(0.18 \% \mathrm{Cu})$ was used in substrate to produce plant seedling, the $\mathrm{pH}$ mean value of 6.73 for the soil layer of $0.0-0.40 \mathrm{~m}$ possibly contributed to the inhibition of the copper absorption by the plants in the moment of the nutritional evaluation.

Irrigation water with $0.35 \mathrm{dS} \mathrm{m}^{-1}$, obtained from surface dam, according to [31], changed the soil salinity degree from non-saline $\left(E C s e<2 \mathrm{dS} \mathrm{m}^{-1}\right)$ to slightly saline soil $\left(2<\mathrm{EC}<4 \mathrm{dS} \mathrm{m}^{-1}\right)$. On the other hand, the saline water $\left(4.00 \mathrm{dS} \mathrm{m}^{-1}\right)$ changed it to moderately saline $\left(4<8 \mathrm{dS} \mathrm{m}^{-1}\right)$ during the period from seedlings transposition to the beginning of plants flowering, regardless of treatments with potassium or bovine biofertilizer (Figure 1). The increase in soil salinity is mostly due to irrigation with the respective waters during 115 days (between 07/17/2013 11/09/2013) after the seedlings transpositions - DAT. It is also a response to the high saline index of $116 \%$ for the $\mathrm{KCl}$ and high electrical conductivity of the biofertilizer $\left(3.1 \mathrm{dS} \mathrm{m}^{-1}\right)$ applied one day before and at 90 DAT.
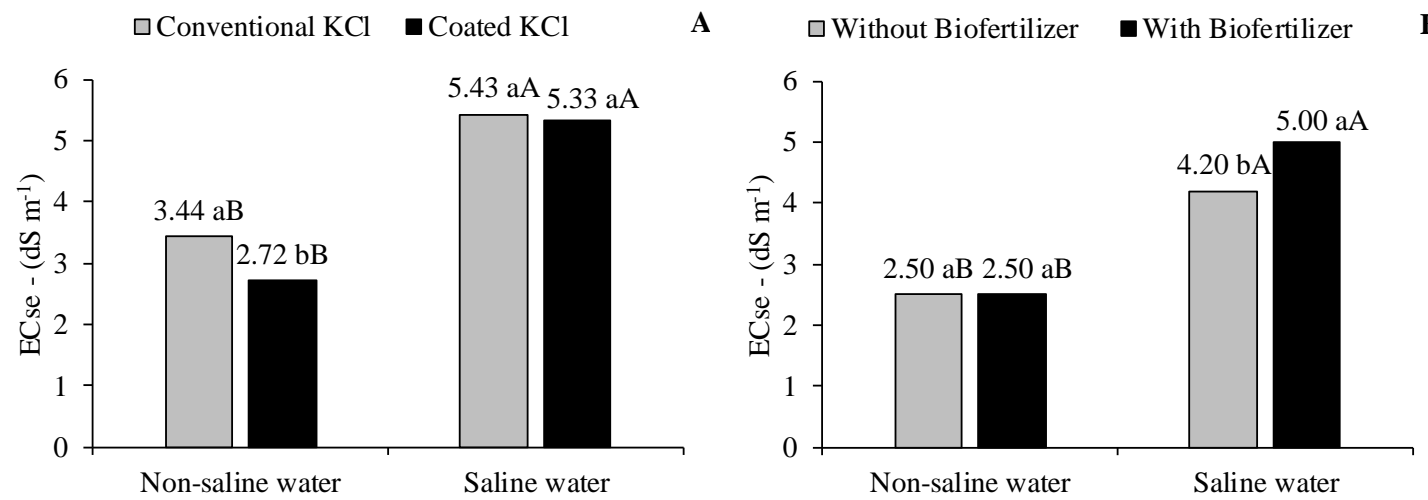

Figure 1: Electrical conductivity of saturation extract of the soil in layer 0.0-0.4 m at the beginning of flowering of passion fruit, at 115 DAT, as function of water salinity in soil with conventional and coated $\mathrm{KCl}(A$, irrigation water $x$ potassium source interaction) without and with biofertilizer $(B$, irrigation water $x$ biofertilizer interaction). Columns with the same small letters considering the irrigation water type $x$ potassium source (A) and irrigation water type $\times$ biorfetilizer application $(B)$ interactions, do not differ among them according to Tukey's test with a probability level of $5 \%$. Columns with the same capital letters for different potassium sources $(A)$ and biofertilizer application $(B)$ irrigated with different water types do not differ among them according to Tukey's test with a probability level of 5\%.

In the soil irrigated with non-saline water, the potassium chloride with slow release of through the coated grains with organic polymers possibly favored salt leaching and consequently reduced the electrical conductivity of the saturation extract -ECse was $20.9 \%$ in relation to the soil fertilized with conventional potassium chloride. In the treatments irrigated with saline water there was no significant statistical variance between the values of ECse due to distinct sources of potassium (Figure 1A). In sandy soils, organic inputs contributed significantly to the increase in porous space, 
particle aggregation, water dynamics and salts leaching from the plants root environment [36]. In the Figure 1B, it can be observed that the soil salinity irrigated with non-saline water did not present differences between the treatments without and with biofertilizer. Although the risks of increasing soil salinity using the biofertelizer, the good quality of the water and the soil texture contributed to obtain no significant effects on the electrical conductivity values between the treatments without and with fermented soil. On the other hand, the same organic compound combined with the saline water increased the soil salinity in $16.9 \%$, as it is compared to the treatment without the compound. Such increment could be a result of the salinity from both, the saline water and the biofertilizer, which have an electrical conductivity of 4.00 and $3.10 \mathrm{dS} \mathrm{m}^{-1}$, each one. Moreover, there is a large presence of ions $\left(\mathrm{Ca}^{++}, \mathrm{Mg}^{++}, \mathrm{Na}^{+}, \mathrm{HCO}^{-3}, \mathrm{SO}_{2}^{-4}\right.$ e Cl$\left.{ }^{-}\right)$in both (Table 2).

Electric conductivity levels of the saturation extract, above $4.0 \mathrm{dS} \mathrm{m}^{-1}$, as those ones obtained in soil under irrigation with saline water $-\mathrm{ECse}=4.0 \mathrm{dS} \mathrm{m}^{-1}$ (Figure 1) injury growth, promote nutritional unbalance, stomatal maladjustment and reduce the productive capacity of most glycophytes [3,31]. These inconveniences reflect negatively on crop growth and yield, as reported by Rameshwaran et al. (2016) [29] with pepper (Capsicum annuum L.) and Vieira et al. (2016) [38] with cherry tomatoes (Lycopersicon esculentum Mill) cultivation. These depressive effects become even more pronounced in plants that are sensitive and moderately sensitive to salinity [4], however, in Regosols, there was no deleterious effects on the production components of passion fruit.

The bovine fertilizer application to soil irrigated with non-saline water and fertilized with coated $\mathrm{KCl}$ reduced the leaf B content from $31 \mathrm{mg} \mathrm{kg}^{-1}$ to $26 \mathrm{mg} \mathrm{kg}^{-1}$, indicating a decrease of $16.1 \%$ in relation to the plants without biofertilizer (Figure 2). This drop possibly occurred due to the competition that is established between the boron and the higher supply of nitrogen provided by the biofertilizer (which contains $2.2 \%$ of $\mathrm{N}$ in dry matter of the pure compound). It limits the availability of this micronutrient in soil and reduces the boron accumulation in the leaf tissue of the plants [21]. In the treatments with saline water and coated $\mathrm{KCl}$, the use of bovine biofertilizer provided an increase in leaf boron content of $20.8 \%$ and a mean concentration of $29 \mathrm{mg} \mathrm{kg}^{-1}$ of B (Figure 2). The boron accumulation in the plants is induced by the contents of potassium, calcium and magnesium in soil [28]. This rise in boron contents may take place due to the low contents of magnesium in soil for the treatments irrigated with saline water, fertilized with coated $\mathrm{KCl}$ and with biofertilizer application [35], i.e., a combination that enables boron accumulation in the leafs of the fruit passion plants.

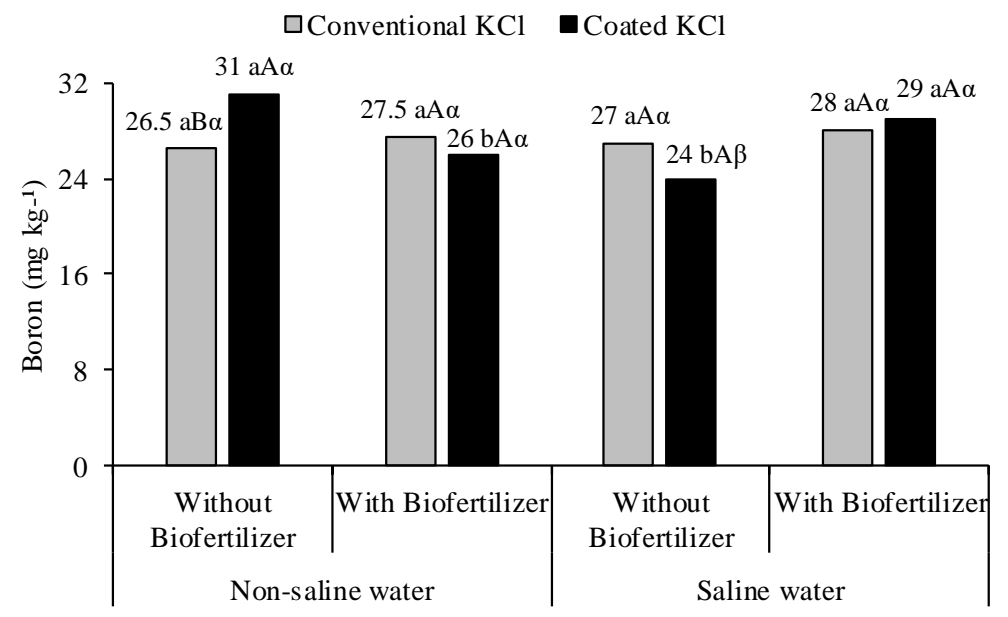

Figure 2: Boron content in the leaf dry matter of the yellow passion fruit plant as a function of the irrigation water type (non-saline and saline), the soil without and with biofertilizer and the potassium source. The columns with the same small letters do not differ in relation to the biofertilizer application or exemption in the soil when the same potassium source and irrigation water type are considered. The columns with the same capital letters do not differ in relation to the potassium source when the biofertilizer application and exemption with the same irrigation water type are considered. The columns with the same greek symbols do not differ in relation to the irrigation water type when the same biofertilizer condition and potassium source are considered. The comparisons were established through Tukey's test with a probability level of $5 \%$. 
When the values of 26.5 and $31.0 \mathrm{mg} \mathrm{kg}^{-1}$ were compared for plants irrigated with non-saline water, without biofertilizer with conventional and coated $\mathrm{KCl}$, it was reported that the organically coated fertilizer provided an increase in leaf boron contents of $17 \%$. When compared with the contents of plants irrigated with non-saline $\left(31.0 \mathrm{mg} \mathrm{kg}^{-1}\right)$ and saline $\left(24.0 \mathrm{mg} \mathrm{kg}^{-1}\right)$ water, without bovine biofertilizer and fertilized with coated $\mathrm{KCl}$, it was verified that water at higher conductivity caused a reduction of the leaf boron contents in the plants of $29.1 \%$. These results, according to Malavolta et al. (1997) [20], present plant levels that are lower than the minimum limit of the range of 40 to $50 \mathrm{mg} \mathrm{kg}^{-1}$ required for adequate crops and thus were deficient in boron. For the substrate formulation used in the plant seedlings production, $1 \%$ of Fosmag, which contains $0.15 \%$ of boron, was applied. Nevertheless, even though the plants presented micronutrient deficiency in the leaf tissue, they do not presented apparent visual symptoms. The $\mathrm{pH}$ value of 6.73 observed in the first $0.40 \mathrm{~m}$ of soil layer may explain the boron adsorption by the media, reducing its availability, and consequently, causing its accumulation in the plant leaf tissues. These results differ from those reported by Freire et al. (2015) [14], who have found that the passion fruit plants grown in the fields irrigated with saline water and $\left(4.0 \mathrm{dS} \mathrm{m}^{-1}\right)$ without biofertilizer on soil had an increase of $25.4 \%$ in foliar boron as compared to those ones irrigated with water at low electrical conductivity $(0.5 \mathrm{dS}$ $\left.\mathrm{m}^{-1}\right)$.

Bovine biofertilizer increased iron contents from 74 to $83.5 \mathrm{mg} \mathrm{kg}^{-1}$, it means an increase of $12.8 \%$ among plants irrigated with non-saline water and fertilized with conventional $\mathrm{KCl}$ in relation to the ones that did not receive the respective organic input. A reverse behavior was observed in treatments irrigated with saline water, where the organic matter reduced leaf iron contents from 89.5 to $78.5 \mathrm{mg} \mathrm{kg}^{-1}$, resulting in a decrease of $14 \%$ in the plants with biofertilization (Figure 3). This decrease can be related to the increase in the $\mathrm{pH}$ values during the nutritional evaluation of the plants, taking into account that there is no meaningful effect of the soil $\mathrm{pH}$. The $\mathrm{pH}$ mean values varied from 6.6 to 6.9 between the treatments with biorfertilizer application and exemption in soil, respectively (in both treatments are considered fertilization with conventional potassium chloride and irrigation with saline water). This fact may be the cause of the iron adsorption inhibition in leafs of the passion fruit plant. However, when comparing the results between plants, except for plants treated with bovine biofertilizer and conventional $\mathrm{KCl}$, irrigation with high salinity water (4 $\mathrm{dS} \mathrm{m}^{-1}$ ) promoted an increase in leaf iron content. The values increased from 78.5 to $89.5 \mathrm{mg} \mathrm{kg}^{-1}$ exceeding the mean value of $55.78 \mathrm{mg} \mathrm{kg}^{-1}$ obtained by Freire et al. (2015) [14] with the same crop submitted to irrigation with water at low and high salinity degree, and using bovine biofertilizer in the soil. However, levels were lower than the minimum value of the critical range of 120 to $200 \mathrm{mg}$ $\mathrm{kg}^{-1}$ [20], showing that the plants, at that time, were deficient in iron. In passion fruit plant crops, such deficiency can reduce leaves size, limit photosynthesis, promote the falling of leaves and decrease green mass [37]. Moreover, there is a reduction of the fruits size and drops in the productivity.

The variation in edaphic $\mathrm{pH}$ from 6.5 to 7.0 and an increased $\mathrm{P}$ content in the soil by fertilization with single superphosphate every 60 days can stimulates low mobility and consequent reduction of $\mathrm{Fe}^{2+}$ accumulation in leaves due to the fact that to rise the $\mathrm{pH}$ reduces the micronutrients availability to plants in general and passion fruit [14]. According to Marschner (2012) [21], in the pH range of 4.0 to 9.0, iron solubilization is decreased up to thousand times for each unit of soil $\mathrm{pH}$ increase. 


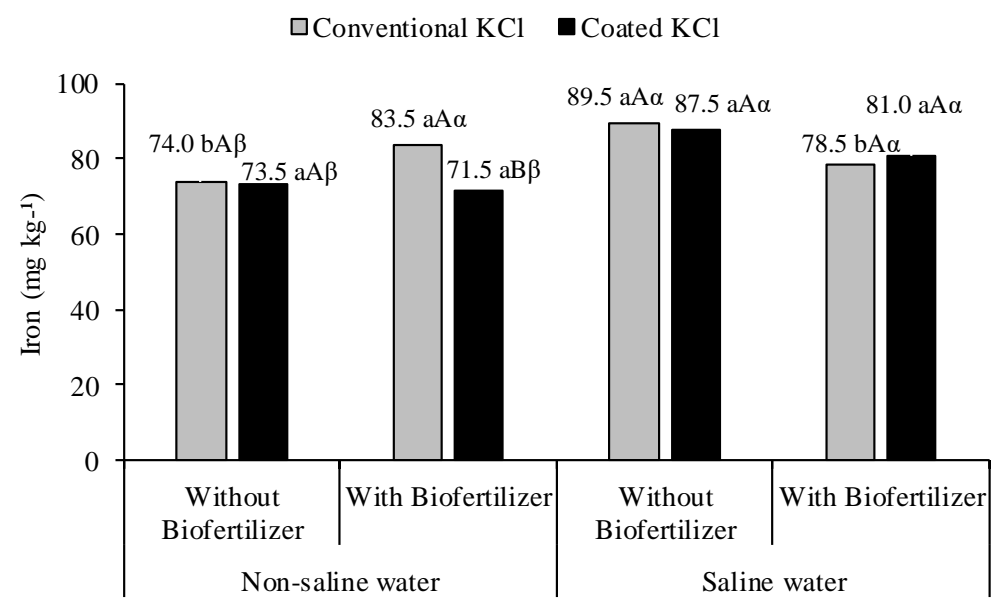

Figure 3: Iron content in the leaf dry matter of the yellow passion fruit plants as a function of the irrigation water type (non-saline and saline), the soil without and with biofertilizer and the potassium sources. The columns with the same small letters do not differ in relation to the biofertilizer application or exemption in the soil when the same potassium source and irrigation water type are considered. The columns with the same capital letters do not differ in relation to the potassium source when the biofertilizer application and exemption with the same irrigation water type are considered. The columns with the same greek symbols do not differ in relation to the irrigation water type when the same biofertilizer condition and potassium source are considered. The comparisons were established through Tukey's test with a probability level of $5 \%$.

The mean values, in terms of manganese contents accumulated in leafs of the passion fruit plant, decreased from 24.4 to $21.8 \mathrm{mg} \mathrm{Kg}^{-1}$ between the plants fertilized with conventional and polymercoated potassium chloride, respectively, i.e., a decrease of $10.6 \%$ (Figure 4A). Although the release of is controlled by the coated potassium, during the nutritional evaluation of the plants, the potassium contents in the soil, which has received coated $\mathrm{KCl}$, were significantly high [35]. It can promote high leaf potassium contents in the treatments irrigated with good-quality water [35], and as consequence, it can also inhibit manganese absorption due to its antagonistic relationship between the potassium availability in the rhizosphere and the contents of manganese in the leaves. For zinc, leaf accumulation was stimulated by the biofertilizer raising its contents from 17.9 to 19.6 $\mathrm{mg} \mathrm{kg}^{-1}$, an increase of $9.5 \%$ (Figure 4B). This increase is a result of the chemical composition in the biofertilizer dry matter, which provides all essential elements and had $148.5 \mathrm{mg} \mathrm{kg}-1$ of zinc before $50 \%$ dilution in water. However, the plants had lower $\mathrm{Mn}^{2+}$ and $\mathrm{Zn}^{2+}$ content levels than those recommended by Malavolta et al. (1997) [20], which range between 40 and $250 \mathrm{mg} \mathrm{kg}^{-1}$ and 25 to $40 \mathrm{mg} \mathrm{kg}^{-1}$, respectively. These results differ from Cavalcante et al. (2011) [8] that have found positive effects of conventional potassium chloride on the availability of manganese in yellow passion fruit plants cultivated in soil irrigated with non-saline water. Regarding the leaf zinc contents, phosphate fertilization, performed twice a month, may have affected the availability of $\mathrm{Zn}^{2+}$ in soil due to the antagonistic relationship between both.

Once the effects of the interaction between irrigation water type $\times$ biofertilizer application were evaluated, it can be evidenced that regardless of the bovine biofertilizer application conditions, the leaf sodium contents in the passion fruit plants were significantly high (Figure 4C). When the values of 0.54 and $5.50 \mathrm{~g} \mathrm{~kg}^{-1}$ are compared in treatments without biofertilizer, and 0.51 and $4.29 \mathrm{~g} \mathrm{~kg}^{-1}$, of the plants treated with the natural input, irrigated with non-saline water and respectively, it is reported that saline water irrigation have promoted increases of $918.5 \%$ and $741.2 \%$ in leaf sodium contents of the plants. In spite of the high values, in both situations, the inferiority of $28 \%$ in the plants irrigated with the saline water and biofertilizer in the soil expressed an attenuation of the respective organic input in the absorption and accumulation of $\mathrm{Na}^{+}$by the yellow passion fruit plants. Even considering this reduction, the foliar levels of sodium are considered very high, exceeding the sum of all micronutrients, as also referenced by Freire et al. (2015) [14]. 


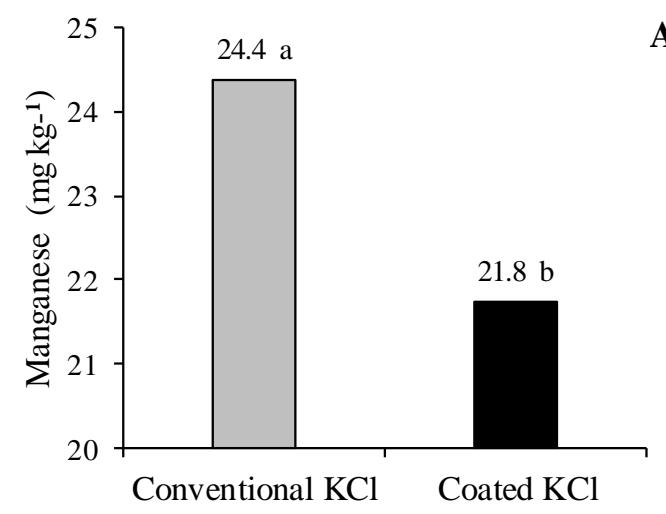

A
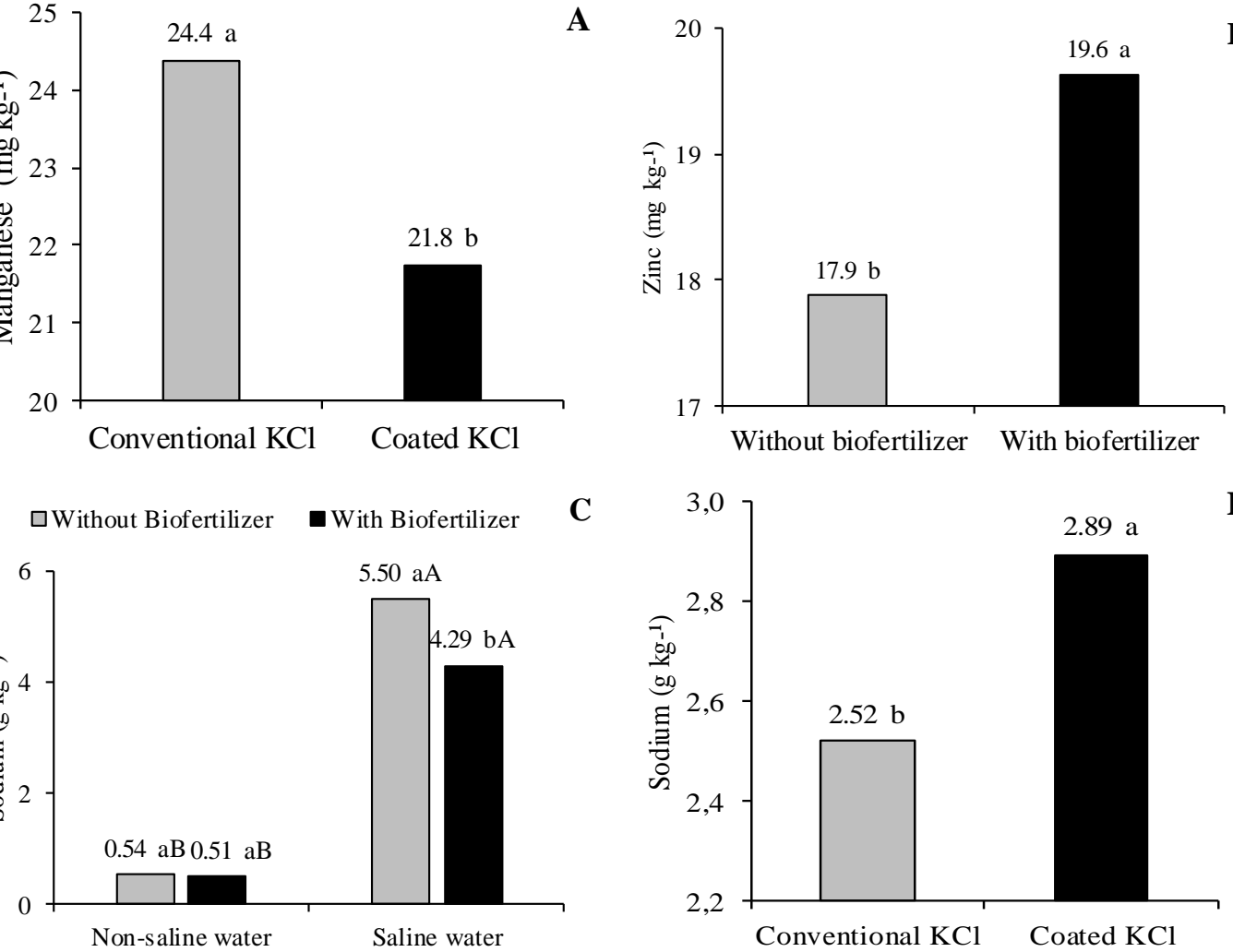

B

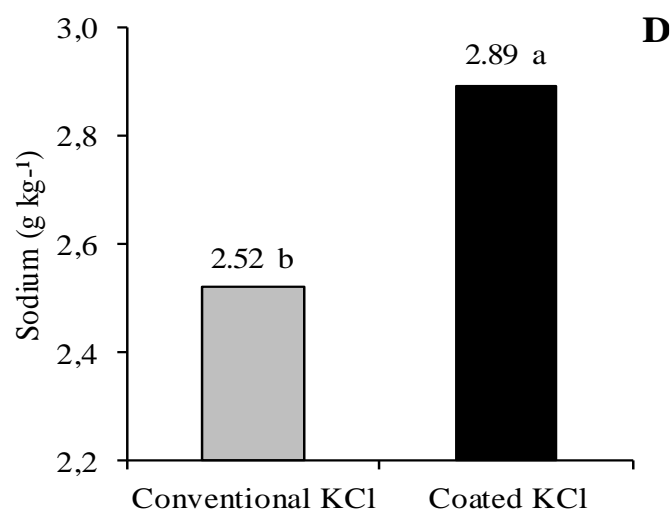

Figure 4: The contentes of manganese $(A)$, zinc $(B)$ and sodium $(C, D)$ in the leaf dry matter of the yellow passion fruit plat as a function of the potassium source $(A, D)$, the biofertilizer application $(B)$ and the irrigation water type - biofertilizer interaction. In the figures $4 A, 4 B$ e $1 D$, according to the Tukey's test with a confidence level of 5\%, the columns with the same small letters present no significant difference. In the figure $4 C$, the mean values with small letters, do not differ in relation to the biofertilizer application or exemption considering the same irrigation water type, while the mean values with capital letters do not differ in relation to the water type irrigation for the same biofertilizer conditions. These comparisons were established through Tukey's test with a confidence level of 5\%.

Fertilization with slow release of $\mathrm{KCl}$ increased leaf sodium content to $2.89 \mathrm{~g} \mathrm{~kg}^{-1}$, expressing an increase of $14.7 \%$ as compared to $2.52 \mathrm{~g} \mathrm{~kg}^{-1}$ of plants fertilized with conventional $\mathrm{KCl}$ (Figure 4D). According to Gheyi et al. (2016) [16] leaf sodium content above $2.5 \mathrm{~g} \mathrm{~kg}^{-1}$ can cause toxicity and compromise the photosynthetic activity of plants, however, in the present work there was no meaningful decrease in the production components of the passion-fruit tree (Figure 5).

The increase of water salinity to a level above the maximum permitted for plants irrigation, which is $3 \mathrm{dS} \mathrm{m}^{-1}$ [4], and the other sources of variation did not have a significant effect on the production components as number of fruits harvested and plants productivity (Figure 5). This situation differs from the literature, when, generally, the increase in salinity of the water inhibits the productive capacity of the fruit, specifically the yellow passion fruit [23, 33].

Despite the absence of significant effects, plants under irrigation with saline water produced on average $7.7 \%$ more fruits than those irrigated with good quality water (Figure 5A). This intensification can be a response of the plant adaptation to the saline stress conditions, which induced a high quantity of fruits with low weight (Figure 5B). Furthermore, the soil physical conditions, with $83.4 \%$ of sand, and the addition of $10 \%$ to the water blade thickness using saline water possibly enabled the salt leaching from the plant root zone. The overall mean of 54 plant $^{-1}$ fruits exceeds 31 plant $^{-1}$ fruits obtained by Soares et al. (2008) [34] cultivating yellow passion fruit crops irrigated with saline water (electrical conductivity of $5.0 \mathrm{dS} \mathrm{m}^{-1}$ ) and resembles to the 51 plant $^{-1}$ fruits harvested by Dias et al. (2012) [9] irrigating the same crop with saline water of $4.5 \mathrm{dS}$ $\mathrm{m}^{-1}$. 

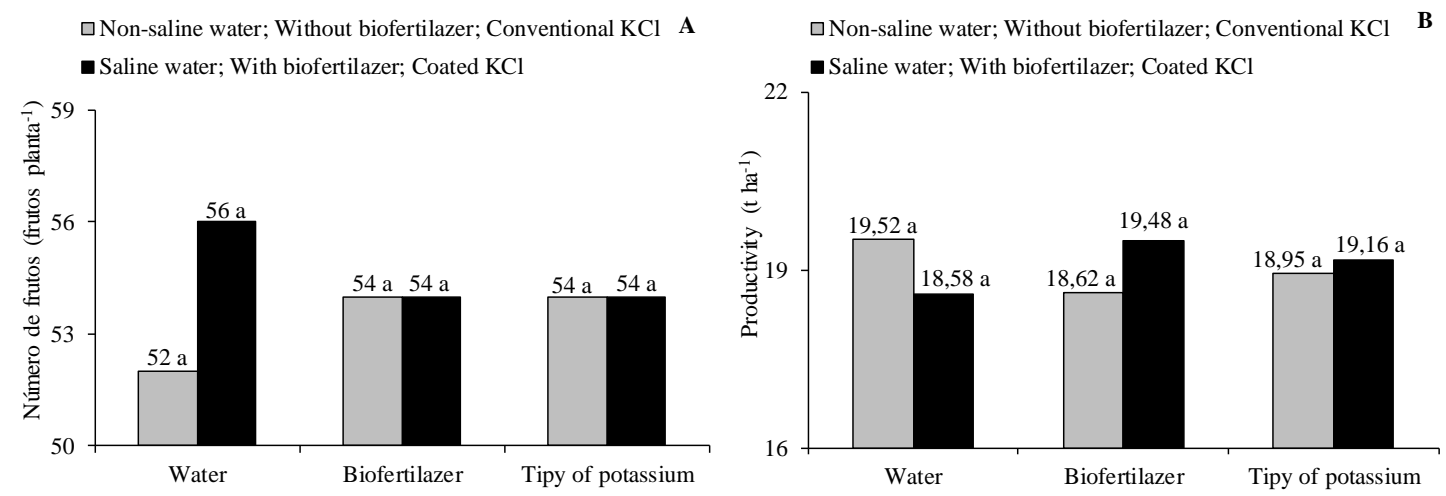

Figure 5: Number of fruits by plant (A) and productivity $(B)$ of the passion-fruit plant irrigated with nonsaline and saline water, using a soil without and with biorfertilizer and fertilization with conventional and coated potassium chloride. According to Tukey's test with a confidence level of 5\%, the columns with the same small letters do not differ in relation to the water type irrigation, biofertilizer conditions or potassium source.

As for productivity (Figure 5B), the increase in water salinity from 0.35 to $4.00 \mathrm{dS} \mathrm{m}^{-1}$, even not significant, showed that the value of $18.58 \mathrm{t} \mathrm{ha}^{-1}$ was promising in relation to the national average yield of $14.1 \mathrm{t} \mathrm{ha}^{-1}$ [19]. It must be also considered that the crop has the production capacity compromised by the increase in the salinity of the irrigation water [26]. This assumption is based on the yield of $4.9 \mathrm{t} \mathrm{ha}^{-1}$ presented by Soares et al. (2008) [33] with yellow passion fruit plant cultivation using saline water $\left(5.0 \mathrm{dS} \mathrm{m}^{-1}\right)$. Despite the deleterious effects of saline water on the depletion of the production capacity of crops, it is verified that irrigation with saline water of 4.00 $\mathrm{dS} \mathrm{m}{ }^{-1}$ did not interfere in the responses of the crop production. It occurs beacause of reducing the osmotic potential of the soil solution, causes a decrease in the $\mathrm{K}^{+} / \mathrm{Na}^{+}$ratio, as generally reported by Anuarbekov et al. (2014) [3]. In addition to the possible benefits brought by the salts leaching, due to the modifications in the soil physical characteristics, the possible increase in the $\mathrm{K}^{+} / \mathrm{Na}^{+}$ ratio, by every month fertilization with $\mathrm{KCl}$, and the attenuation of the humic substances from the biofertilizer may have favored the osmotic regulation of plants [17, 37].

\section{CONCLUSION}

The increase in the electrical conductivity of the irrigated water increased the initial soil salinity from 0.36 to 3.44 and after to $5.43 \mathrm{dS} \mathrm{m}^{-1}$. It also increased the contents of $\mathrm{Fe}^{2+}$ and $\mathrm{Na}^{+}$in the leaves of the passion fruit plant; however, the productivity capacity of the yellow passion fruit plant was not affected.

The passion fruit plants cv BRS Gigante Amarelo at the beginning of the flowering were deficient in boron, copper, iron, manganese and zinc.

The leaf sodium content exceeded the sum of all micronutrients.

The application of coated potassium chloride has inhibited the manganese accumulation in the leaves of the yellow passion fruit plant; on the other hand, it has stimulated the sodium accumulation in the leaf tissues

Despite the absence of significant effect among the sources of variation in plants capacity production, the productivity values of the crop under irrigation with saline water exceeded the Brazilian average numbers.

\section{REFERENCES}

1. Aguiar AVM, Cavalcante LF, Silva RM, Dantas TAG, Santos EC. Effect of biofertilization on yellow passion fruit production and fruit quality. Rev Caatinga. 2017;30(1):136-148, doi: 10.1590/198321252017v30n115rc.

2. Alvares CA, Stape JL, Sentelhas PC, Gonçalves JLM, Sparovek G. Köppen's climate classification map for Brazil. Meteorol Z. 2013;22(6):711-728, doi: 10.1127/0941-2948/2013/0507.

3. Anuarbekov K, Zubairov O, Nusipbekov M. Improving water-salt regime in irrigated agriculture. Life Sci J. 2014;11(5):459-464.

4. Ayers RS,Westcot DN. Water quality in agriculture. 2.ed. Campina Grande-PB: UFPB; 1999. 153 p. 
5. Baath GS, Shukla MK, Bosland PW, Steiner RL, Walker SJ. Irrigation water salinity influences at various growth stages of Capsicum annuum. Agric Water Manag. 2017;179(1):246-253, doi: 10.1016/j.agwat.2016.05.028.

6. Benbouali EH, Hamoudi SAEA, Larich A. Short- term efect of organic residue incorporation on soil aggregate stability along gradient in salinity in the lower cheliff plain (Algeria), Afr J Agric Res. 2013;8(19):2144-2152, doi: 10.5897/AJAR2013.6981.

7. Borges AL. Mineral nutrition, liming and fertilization of irrigated passion fruit. EMBRAPA; 2002.8 p.

8. Cavalcante LF, Rodrigues AD, Diniz AA, Fernandes PD, Nascimento J, Oliveira F. Micronutrients and sodium in a soil cultivated with yellow passion fruit, with the application of biofertilizer supermagro and potassium. Rev Bras Ciên Agrár. 2011;6(3):376-382.

9. Dias TJ, Cavalcante LF, Nunes JC, Freire JLO, Nascimento JAM. Physical quality and production of yellow passion fruit in soil with biofertilizer irrigated with salt water. Semina: Ciên Agrár. 2012; 33(1):2905-2918.

10. Dias TJ, Cavalcante LF, Pereira WE, Freire JLO, Souto AGL. Irrigation with saline water in soil with bovine biofertilizer on the growth of yellow passion fruit. Semina: Ciên Agrár. 2013;34(4):1639-1652, doi: 10.5433/1679-0359.2012v33Supl1p2905.

11. Empresa Brasileira de Pesquisa Agropecuária, EMBRAPA. Brazilian Soil Classification System. 2.ed. Rio de Janeiro, Embrapa Solos; 2013. 602 p.

12. Empresa Brasileira de Pesquisa Agropecuária, EMBRAPA. Manual de análises químicas de solos, plantas e fertilizantes. 2.ed. Embrapa Solos; 2009. 567 p.

13. Feng G, Zhang Z, Wan Changyu LP, Bakoura A. Effects of saline water irrigation on soil salinity and yield of summer maize (Zea mays L.) in subsurface drainage system. Agric Water Manag. 2017;193(1):205-213, doi: 10.1016/j.agwat.2017.07.026.

14. Freire JLO, Cavalcante LF, Dias TJ, Dantas MMM, Medeiros LPM, Azevedo TAO. Micronutrient content in soil and leaf tissue of yellow passion fruit under the use of attenuators of saline stress. Agropecu Téc. 2015;36(1):65-81.

15. Freire JLO, Dias TJ, Cavalcante LF, Fernandes PD, Lima Neto AJ. Quantum yield and gas exchange in yellow passion fruit under water salinity, biofertilization and mulch. Rev Ciênc Agron. 2014;45(1):8291.

16. Gheyi HR, Dias NS, Larcerda CF, Gomes Filho E. Salinity management in agriculture: Basic and applied studies. 2.ed. Fortaleza, INCTSal; 2016. Chapter 11, Effects of salts on the plant and crop tolerance to salinity; p. 151-161.

17. Glaeser LC, Vitt SE, Ebbs S. Responses of the wetland grass, Beckmanniasyzigachne, to salinity and soil wetness: Consequences for wetland reclamation in the oil sands area of Alberta, Canada. Ecol Eng. 2016;86(1):24-30, doi: 10.1016/j.ecoleng.2015.10.009.

18. Holthusen D, Reeb D, Horn R. Influence of potassium fertilization, water and salt stress, and their interference on rheological soil parameters in planted containers. Soil \& Tillage Res. 2012;125(2):72-79, doi: 10.1016/j.still.2012.05.003.

19. IBGE Instituto Brasileiro de Geografia e Estatística. (2016) - Rio de janeiro. Produção 2016. Acesso em 01 de setembro de 2018. Disponível em http://www.sidra.ibge.gov.br/bda/agric/.

20. Malavolta E, Vitti GC, Oliveira AS. Avaliação do estado nutricional das plantas. Princípios e aplicações. Piracicaba, Potafos; 1997. 197 p.

21. Marschner P. Mineral Nutrition of Higher Plants. 3. ed. London, Elsevier; 2012. 324 p.

22. Mesquita FO, Cavalcante LF, Rebequi AM, Lima Neto AJ, Nunes JC, Nascimento JAM. Production of yellow passion fruit seedlings on substrate with bovine biofertilizer irrigated with salt water. Agropecu Téc. 2010;31:134-142.

23. Nascimento JAM, Cavalcante LF, Cavalcante IH, Pereira WE, Dantas SAG, Medeiros SAS. The impacts of biofertilizer and mineral fertilization on the growth and production of yellow passion fruit irrigated with moderately saline water. Cienc Investig Agr. 2016;43(2):253-262.

24. Nassah H, Er-raki S, Khabba S, Fakir Y, Raibie F, Merlin O, Mougenot B. Evaluation and analysis of deep percolation losses of drip irrigated citrus crops under non-saline and saline conditions in a semi-arid área. Biosyst Eng. 2018;165(1):10-24, doi: 10.1016/j.biosystemseng.2017.10.017.

25. Nogueira E. Coeficiente de cultivo e lâminas de irrigação do maracujazeiro amarelo nas condições semiáridas. [Dissertação de Mestrado]. Fortaleza-CE; Universidade Federal do Ceará; $2011.70 \mathrm{f}$.

26. Nunes JC, Cavalcante LF, Pereira WE, Souza JTA, Almeida DJ, Oresca D, Fernandes PD. Gas exchange and productivity of yellow passion fruit irrigated with saline water and fertilized with potassium and biofertilizer. Cienc Investig Agr. 2017;44(2):168-183, doi: 10.7764/rcia.v44i2.1742.

27. Oliveira FIF, Medeiros WJF, Cavalcante LF, Cavalcante ÍHL, Souto AGL, Lima Neto AJ. Crescimento e produção do maracujazeiro amarelo fertirrigado com esterco bovino líquido fermentado. Rev Agropecu Téc. 2017;38(4):191-199. 
28. Ortega AE, Malavolta E. Los más recientes micronutrientes vegetales. Informac Agron Hispanoam. 2012;7(1):16-25.

29. Rameshwaran P, Tepe A, Yazar A, Ragab R. Effects of drip-irrigation regimes with saline water on pepper productivity and soil salinity under greenhouse conditions. Sci Hortic. 2016;199(16):114-123, doi: 10.1016/j.scienta.2015.12.007.

30. Rebequi AM, Cavalcante LF, Diniz AA, Nunes JC, Brehm MAS, Oliveira FA. Growth and production of yellow passion fruit under different levels and combinations of nitrogen and potassium fertilization in soil and foliar in plants. Magistra. 2011;23(1):35-42.

31. Richards LA. Diagnosis and improvement of saline and alkaline soils. Washington, United States Salinity Laboratory Staff; 1954. 172 p.

32. SAS Institute Inc. SAS/STAT 9.3 User's Guide. Cary; 2011. 8621 p.

33. Soares FAL, Carneiro PT, Gomes EM, Gheyi HR, Fernandes PD. Growth and production of yellow passion fruit under supplementary irrigation with saline water. Rev Bras Ciênc Agrár. 2008;3(2):151-156, doi: 10.5039/agraria.v3i2a196.

34. Souza JTA, Cavalcante LF, Nunes JC, Bezerra FTC, Nunes JAS, Silva AR, Oresca D, Cavalcante AG. Effect of saline water, bovine biofertilizer and potassium on yellow passion fruit growth after planting and on soil salinity. Afr J Agric Res. 2016;11(32):2994-3003, doi: 10.5897/AJAR2016.11233.

35. Souza JTA. Saline, potassium and biofertilizer water in the soil, growth, mineral composition and yellow passion fruit production [Masters dissertation]. Areia-PB; Federal University of Paraíba; 2016. 96p.

36. Stefanoski DC, Santos GG, Marchão RL, Petter FA, Pacheco LP. Soil use and management and its impacts on physical quality. Braz J Eng Agríc Amb. 2013;17(12):1301-1309.

37. Toledo RL. Deficiência de micronutrientes e efeito do niquel no estado nutricional do maracujazeiro amarelo (Passiflora edulis Sims). [Dissertação de Mestrado]. Jaboticabal-SP; Universidade Estadual Paulista; 2017. 87p.

38. Vieira IGS, Nobre RG, Dias NS, Francisco WA, Pinheiro FWA. Cultivation of cherry tomato under irrigation with saline water and nitrogen fertilization. Rev Bras Eng Agríc Amb. 2016;20(1):55-61, doi: 10.1590/1807-1929/agriambi.v20n1p55-61.

39. Wang X, Yang J, Liu G, Yao R, Yu S. Impact of irrigation volume and water salinity on winter wheat productivity and soil salinity distribution. Agric Water Manag. 2015;149:44-54, doi: 10.1016/j.agwat.2014.10.027.

40. Yang X, Lia C, Zhang Q, Liu Z, Geng J, Zhang M. Effects of polymer-coated potassium chloride on cotton yield, leaf senescence and soil potassium. Field Crops Res. 2017;212(2):145-152, doi: 10.1016/j.fcr.2017.07.01. 